\title{
Erratum to: Linagliptin: a review of its use in the management of type 2 diabetes mellitus
}

\author{
Emma D. Deeks
}

Published online: 22 January 2013

(C) Springer International Publishing Switzerland 2013

Erratum to: Drugs (2012) 72:1793-1824

DOI 10.2165/11209570-000000000-00000

Page 1804, column 1, section 5.3.1, paragraph 2, which previously read:

"Significantly ${ }^{[12]}$ or numerically ${ }^{[11,54]}$ more patients in the linagliptin than in the placebo groups achieved an $\mathrm{HbA}_{1 \mathrm{c}}$ level of $\leq 7.0 \%$ (table IV) ${ }^{[11,12]}$ or $<6.5 \%$ (10\% vs $2 \%$; OR 5.5; $\mathrm{p}<0.0016),{ }^{[12]}$ a reduction in $\mathrm{HbA}_{1 \mathrm{c}}$ of $\geq 0.5 \%$ (table IV) ${ }^{[12,54]}$ or required rescue therapy ( $8 \%$ vs $19 \%$; OR $0.28 ; \mathrm{p}=0.0001)$. ${ }^{[12]}$,

Should read:

"Significantly ${ }^{[12]}$ or numerically ${ }^{[11,54]}$ more patients in the linagliptin than in the placebo groups achieved an $\mathrm{HbA}_{1 \mathrm{c}}$ level of $\leq 7.0 \%$ (table IV) ${ }^{[11,12]}$ or $<6.5 \%$ (10\% vs $2 \%$; OR $5.5 ; \mathrm{p}<0.0016)^{[12]}$ or a reduction in $\mathrm{HbA}_{1 \mathrm{c}}$ of $\geq 0.5 \%$ (table IV), ${ }^{[12,54]}$ and significantly fewer linagliptin than placebo recipients required rescue therapy (8\% vs 19\%; OR $0.28 ; p=0.0001) .{ }^{[12]}$ "

The online version of the original article can be found under doi:10.2165/11209570-000000000-00000.

E. D. Deeks $(\bowtie)$

Adis, 41 Centorian Drive, Private Bag 65901, Mairangi Bay,

North Shore 0754, Auckland, New Zealand

e-mail: demail@springer.com 